\title{
The Prevalence of Thyroid Nodules in Children with Family History for Nodular Goiter
}

\author{
Ailesinde Nodüler Guatr Olan Çocukların Tiroid Lezyon Prevalansı \\ Zuhal Aşık $k^{l}$ (iD Hakan Aylanç ${ }^{1}$ \\ ${ }^{1}$ Çanakkale Onsekiz Mart Üniversitesi Tıp Fakültesi Çocuk Sağlığı ve Hastalıkları Ana Bilim Dalı, Çanakkale, Türkiye
}

\section{ÖZET}

Giriş: Nodüler guatrın genetik olarak kümelenmesi ile ilgili yeterli çalışma yoktur. Her ne kadar ikiz çalışmaları genetik bir kümelenme göstermişse de, bu konuyla ilgili yapılmış prospektif bir çalışma yoktur. Bu çalışmanın amacı ailesinde nodüler guatrı olan çocuklardaki nodül prevelansının değerlendirilerek ailesel kümelenmenin varlığının araştırılmasıdır.

Yöntem: Ailesinde nodüler guatr tespit edilen ve edilmeyen çocukların tiroit ultrasonu ile değerlendirilerek nodül prevelansı hesaplanmıştır.

Bulgular: Tüm çocukların 5'inde $(\% 3,4)$ nodüler guatr saptandı. Ailesinde nodüler guatr öyküsü olan çocukların 2'sinde $(\% 2,5)$, kontrol grubundaki çocukların 3'ünde $(\% 4,7)$ nodüler guatr tespit edildi. 2 grup arasında istatistiksel olarak anlamlı fark saptanmadı.

Sonuç: Bu çalışma nodüler guatr hastalığının ailesel yönünü araştıran ilk prospektif çalışmadır. Çalışmamızda nodüler guatrlı hastaların çocuk kitlesi hedeflenmiştir. Yapılan istatistiksel analiz sonucunda MNG'lı hastaların çocuklarında nodüler guatrın kümelenmediği izlenmiştir.

Anahtar Kelimeler: çocuk, guatr, tiroit nodülleri

\begin{abstract}
Introduction: There is insufficient study on the genetic clustering of nodular goiter. Although twin studies have proved genetic clustering, there is no prospective study on this topic. The aim of this study is to investigate the existence of familial clustering by evaluating the prevalence of thyroid nodules in the children of families with nodular goiter.

Methods: The prevalence of thyroid nodules was calculated by evaluating the thyroid ultrasound results of children from families with and without nodular goiter.

Results: Nodular goiter was detected in 5 children (3.4\%), 2 (2.5\%) from families with nodular goiter history and 3 (4.7\%) from the control group. There was no statistically significant difference between these two groups.

Conclusions: This is the first prospective study to investigate the familial aspect of nodular goiter disease. In our study, children with nodular goiter were the target group. Following statistical analysis, clustering of nodular goiter was observed in the children of patients with multinodular goiter.

Keywords: children, goiter, thyroid nodules
\end{abstract}

Başvuru / Submission: Ağustos / Aug 10, 2017

Kabul / Acceptance: Aralık / Dec 13, 2017

Yazışma / Correspondence: Dr. Hakan Aylanç, Çanakkale Onsekiz Mart Üniversitesi Tıp Fakültesi Çocuk Sağlığı ve Hastalıkları Ana Bilim Dalı, Çanakkale, Türkiye

E-Mail: draylanc@ hotmail.com 


\section{INTRODUCTION}

Thyroid nodules are observed more rarely in children compared to adults. ${ }^{1}$ Nodule prevalence is estimated to be $0.2-5 \%$ in children vs. $19-35 \%$ in adults . ${ }^{2-5}$ However, pediatric thyroid nodules have a higher likelihood of malignancy compared with those in adults with cancer diagnosed in approximately $10 \%$ of thyroid nodules in adults and up to $25 \%$ of those in children. ${ }^{1,5-7}$ Retrospective studies in recent years have determined the prevalence of palpable thyroid nodules in children is $1.79 \% .{ }^{8}$ Ultrasonography studies have determined the nodule prevalence in the pediatric age group is $0.2-5.1 \% .^{2,9}$

Though factors like genetics and iodine deficiency are blamed for the pathogenesis of nodular goiter, it is not fully understood. The clustering of nodular goiter in families and the high incidence in monozygotic twins leads to consideration of the contribution of genetic factors. ${ }^{10}$ However, no clear hereditary transition or certain gene locus has been identified. Several genes are blamed for familial clustering of nodular goiter cases. These include the TSH receptor gene, thyroglobulin gene and Na+/I- symporter gene. ${ }^{5}$ Any disruption in these genes may cause nodular goiter. Though disruption of these genes have been shown in some families, these patients comprise only a very small portion of nodular goiter cases.

Nodular goiter increases with age, though there is no study assessing the incidence of nodular goiter in the children of adults with nodular goiter. Additionally, if nodules are commonly observed in the children of parents with nodular goiter, early identification of this situation and treatment of these patients will provide additional benefit due to the high incidence of cancer in these nodules. The aim of our study is to assess the incidence of nodular goiter in the children of families with nodular goiter history.

\section{METHODS}

The study group was determined as the under 18-year old children of patients applying to Çanakkale Onsekiz Mart University Faculty of Medicine Endocrinology and Metabolism Clinic with diagnosis and monitoring for nodular goiter and the patient relatives and their under 18-year old children of those applying to the pediatric clinic with multinodular goiter previously diagnosed by an endocrinologist. The control group was chosen from children applying to the Pediatric Health and Diseases clinic with no parental or family history of thyroid disease. Both parents and all children had thyroid ultrasound performed. Parents and children with nodular goiter identified among these patients were removed from the control group and included in the patient group. Volunteers participating in the study were questioned about number of family members, closeness to index case, health situation, diseases and medications used.

Nodular goiter was identified by finding nodules on physical examination and ultrasound of the thyroid. The index case and patients with nodular goiter identified during screening were directed to the relevant department for evaluation of thyroid functions and pathology.

Cases included in the study were assessed with a high frequency ultrasound (GE, LOGIQ P5, USA) with a $10 \mathrm{MHz}$ transducer. The thyroid ultrasound was performed by a radiologist.

The thyroid volume for all cases was calculated with the following Delange formula: Thyroid volume $=$ height $(\mathrm{cm}) \mathrm{x}$ width $(\mathrm{cm}) \mathrm{x}$ depth $(\mathrm{cm}) \times 0.479 .{ }^{11}$

All children showed signs of pubertal development at pubertal stage 2+ according to Tanner staging criteria. Blood samples from all children were obtained by venipuncture in the morning after a fasting period of at least $8 \mathrm{~h}$. TSH levels were measured using a Cobas e-601 auto-analyzer device (Roche Diagnostics, Indianapolis, Ind., USA). Hormones were measured with the same device by an electrochemiluminescence immunoassay method.

\section{Statistical Analysis}

The data were analyzed using SPSS version 19.0 software (SPSS/Windows version 19.0; SPSS, Inc., Chicago, Ill., USA). Statistical difference was accepted as significant at $\mathrm{p}<0.05$. All numerical data are shown as median. Differences in nominal data between the groups was assessed with the Chi square test. Normal distribution of data was evaluated with the Kolmogorov Smirnov test. Groups with normal distribution were tested with the Students t test, while the Mann-Whitney U test was used for groups with non-normal distribution. 


\section{Statement of Ethics}

The study was conducted according to the Declaration of Helsinki, and the study protocol was approved by the Ethical Committee of the Canakkale Onsekiz Mart University. Signed informed consent was obtained from all study participants, and informed parental consent was obtained for all children regardless of age.

\section{RESULTS}

The study included 103 families for a total of 292 cases. Within the group, 145 patients were pediatric cases and 147 patients were adult cases. The nodular goiter group included 56 families, while the control group included 47 families. The nodular goiter group comprised 81 child $(50.3 \%)$ and 80 adult $(49.7 \%)$ patients. In the group $104(64.6 \%)$ were female and $57(51.1 \%)$ were male. The control group comprised 64 child $(48.9 \%)$ and $67(51.1 \%)$ adult patients. In this group there were 80 female patients $(61.1 \%)$ and 51 male patients (38.9\%). The median age of pediatric patients in the MNG group was 8 years (0.5-17 years), and in the control group was 9.5 years (117 years). None of the children in the nodular goiter and control groups had growth and development retardation. The general characteristics of pediatric patients are summarized in Table 1. The median age of adult patients in the nodular goiter group was 40 years (22-62 years) and in the control group was 35 years (24-58 years). There was no difference identified between the nodular goiter and control groups in terms of gender and age of pediatric patients. While there was no difference identified between the nodular goiter group and the control group for gender of adult patients, age was found to be significantly different $(\mathrm{p}<0.001)$.

\section{Table 1. Clinical characteristics of pediatric patients}

\begin{tabular}{llll}
\hline & $\begin{array}{l}\text { NG group } \\
(\mathrm{n}=81)\end{array}$ & $\begin{array}{l}\text { Control group } \\
(\mathrm{n}=64)\end{array}$ & $P$ value \\
Gender (F/M) & $44 / 37$ & $33 / 31$ & $n s^{*}$ \\
Age (median, years) & $8(0.5-17)$ & $9.5(1-17)$ & $n s^{\beta}$ \\
Thyroid volume (median, ml) & $3.8(0.8-19.4)$ & $4.25(1-13.9)$ & $n s^{\beta}$ \\
New NG case n & $2(2.5 \%)$ & $3(4.7 \%)$ & $n s^{\beta}$ \\
\hline
\end{tabular}

NG: nodular goiter; ns: not significant. ${ }^{*}$ Chi-square test; ${ }^{\beta}$ mann-whitney $U$ test

Of all children, $64(44.1 \%)$ had entered puberty while 81 were prepubertal $(55.9 \%)$. Nodular goiter was identified in 2 children in the prepubertal period $(2.5 \%)$ and 3 children in puberty $(4.7 \%)$. Nodule incidence was similar in both groups $(\mathrm{P}>0.05)$.

The median thyroid volume in pediatric patients in the nodular goiter group was $3.8 \mathrm{ml}(0.8-19.4 \mathrm{ml})$ and this was $4.25 \mathrm{ml}(1-13.9 \mathrm{ml})$ in the control group. The median thyroid volume in adult patients in the nodular goiter group was $14 \mathrm{ml}(3.7-129 \mathrm{ml})$ and this was 9.95 $\mathrm{ml}(3.1-22.3 \mathrm{ml})$ in the control group. The median nodule size in children in the nodular goiter group was $9.5 \mathrm{~mm}(3-16 \mathrm{~mm})$ and this was $8 \mathrm{~mm}(4-8 \mathrm{~mm})$ in the control group. There was no difference identified for thyroid volume of pediatric cases in the nodular goiter and control groups. There was a significant difference in thyroid volume of adult cases in the nodular goiter group compared to the control group $(\mathrm{P}<0.001)$.

Among all children, 5 (3.4\%) were identified with nodular goiter. The general characteristics of pediatric patients with nodular goiter identified are summarized in Table 2. Nodular goiter was identified in 2 children $(2.5 \%)$ with nodular goiter in the family (Figure 1) and in 3 children $(4.7 \%)$ in the control group. There was no statistically significant difference identified between the two groups.

Table 2. Characteristics of patients with nodules identified

\begin{tabular}{llllll}
\hline & Case I & Case II & Case III & Case IV & Case VI \\
\cline { 2 - 6 } Age (year) & 2 & 8 & 17 & 17 & 17 \\
Gender & $\mathrm{F}$ & $\mathrm{F}$ & $\mathrm{M}$ & $\mathrm{F}$ & $\mathrm{F}$ \\
NG family history & + & - & + & - & - \\
Puberty & - & - & + & + & + \\
TSH (IU/ml) & 2.4 & 1.5 & 1.9 & 1.6 & 1.4 \\
fT4 (ng/dL) & 1.4 & 1.3 & 1.6 & 1.7 & 1.1 \\
Nodule size (mm) & 3 & 8 & 8 & 4 & 16 \\
FNAB & - & - & - & - & + \\
FNAB results & - & - & - & - & Benign \\
\hline
\end{tabular}

NG: nodular goiter; FNAB: Thyroid fine needle aspiration biopsy; Normal intervals for TSH and fT4:0.27-4.2 IU/Ml and 0.9-1.7 ng/dL. 


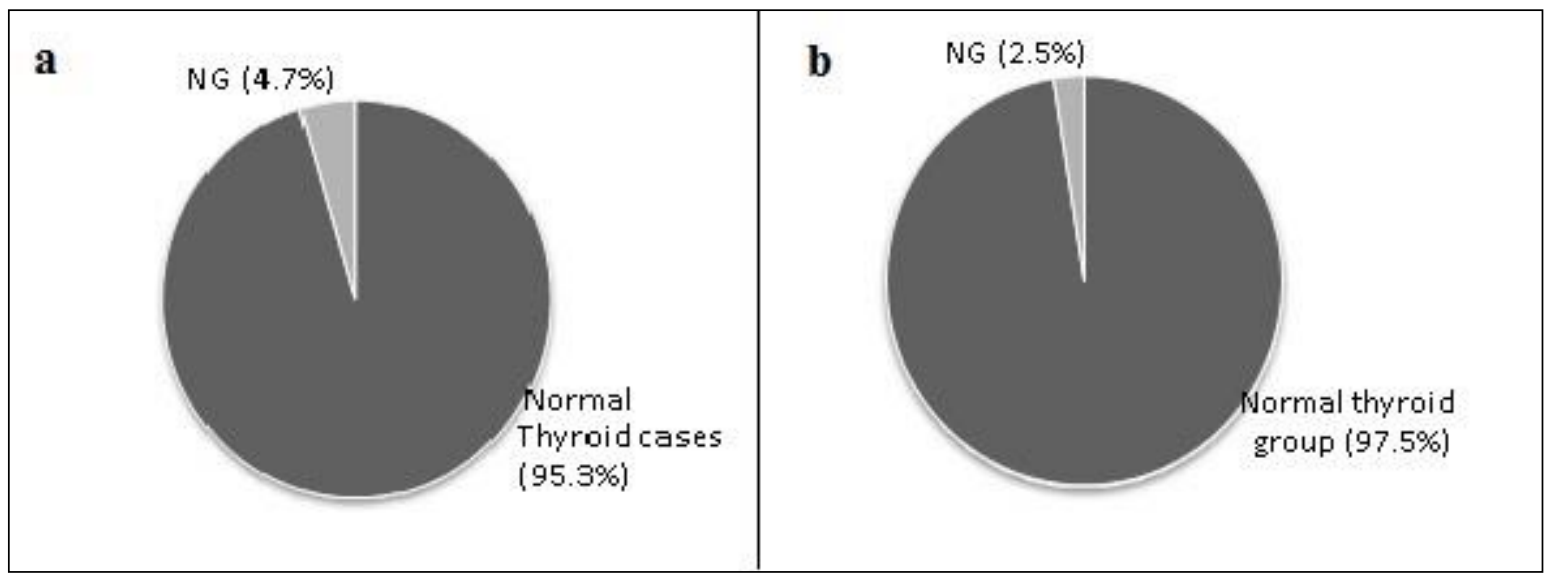

Figure 1. Rate of MNG cases in the MNG pediatric group (a). Rate of MNG cases in the pediatric control group (b).

In pediatric patients with nodule size of $16 \mathrm{~mm}$, thyroid find needle aspiration biopsy (FNAB) was performed due to indications. ${ }^{5}$ Thyroid FNAB results are reported according to Bethesda criteria. These criteria are classified as nondiagnostic/unsatisfactory, benign, atypia/follicular lesion of undetermined significance (AUS/FLUS), follicular neoplasm/suspicion for a follicular neo-plasm (FN/SFN), suspicious for malignancy (SFM), and malignant. ${ }^{12}$ Biopsy cytology results were assessed as benign. As the nodules of the other cases were smaller than $1 \mathrm{~cm}$ and there were no suspicious findings on ultrasound, biopsy was not performed. Patients will be monitored by the clinic.

\section{DISCUSSION}

This study is the first prospective study researching the familial aspect of nodular goiter disease. In our study the target was the children of patients with nodular goiter. Statistical analysis results showed that nodular goiter did not cluster in the children of patients with nodular goiter.

Among thyroid diseases, especially autoimmune thyroid diseases and thyroid cancer apart from medullar thyroid cancer, familial clustering has been shown in prospective studies. ${ }^{13,14}$ Studies researching nodular goiter have observed nodular goiter is more common in twins. ${ }^{10,15}$ These studies lead to consideration of the contribution of a genetic factor in nodular goiter patients. However, to date there is no prospective evaluation performed on this topic. Though twin studies lead to consideration of a genetic tendency, in our study there was no difference observed in clustering of nodular goiter in families with nodular goiter compared to those without.

In studies assessing the nodule incidence with thyroid ultrasound in children, nodule prevalence is $0.2-5.1 \% .^{2,8}$ In our study, the nodule incidence among all children assessed with thyroid ultrasound was in accordance with the literature. Additionally, nodule history in the patients' family did not cause an increase in the prevalence of thyroid nodules.

Endocrine cancers are very rarely observed in the childhood period. Thyroid malignancies comprise $0.5-3 \%$ of all childhood cancers. ${ }^{16}$ However, rates of up to $25 \%$ thyroid cancer within thyroid nodules may be observed in childhood. ${ }^{1,2}$ Studies in Turkey have found thyroid malignancy in the results of FNAB of thyroid nodules was 4.5-13\%. ${ }^{17,18}$ In our study, thyroid nodules were found in 5 pediatric patients. In 1 of these patients, thyroid fine needle aspiration biopsy was performed due to indications. The pathology results for this patient were benign. Monitoring with thyroid ultrasound did not identify any growth in any nodule among these patients.

The incidence of nodular goiter increases with age. However, there is no clear boundary for onset age of disease. The reason for the lack of difference between the 2 groups in our patients, may be that our patients are younger than this onset age. As a result, monitoring the results of thyroid ultrasounds of current patients every 1-2 years may reveal a difference. Additionally, this type of study may provide an idea of the age that nodular goiter occurs.

Thyroid nodules are rare in the prepubertal period. Studies have found this rate is below $1.5 \% .^{1,2}$ However, this rate was higher in our study. Additionally, there was no difference identified in the incidence of nodular goiter between the prepubertal and pubertal groups. The reason for this may be linked to the low number of pediatric patients with nodular goiter. 
Diffuse and nodular goiter is unavoidable in those living in regions with iodine deficiency. In Turkey community screening in the childhood period for iodine deficiency has been performed and in the year 2000 iodine was added to salt in the country in general due to iodine deficiency and studies completed to solve this problem. Studies after the use of iodine salt began found that though iodine deficiency improved slightly, the problem continued in some regions. ${ }^{19,20}$ Unfortunately, no such study was performed for Çanakkale. In our adult cases, the thyroid volume in the nodular goiter group was significantly greater compared to the control group. However, there was no difference identified in the children of these patients. The reason for this may be that the increased iodine in salt after the year 2000 may have caused a general reduction in thyroid volumes in the Çanakkale region. As we did not measure iodine in urine in our patients, and as we do not know the iodine situation in Çanakkale generally before iodinization studies, it is not possible to state this definitively.

\section{CONCLUSION}

In conclusion, nodule incidence is not increased in the children of nodular goiter patients. However, as this age group is young for nodule development, the difference in nodule incidence may have been missed. The general reduction in nodule incidence due to the effect of iodinization studies may be reflected in our patients. A small number of working groups is a limiting factor in our work. As a result, there is a need for broader cohort studies to monitor patients from the childhood period to adulthood.

Acknowledgement: Thank you very much to the parents and children who agreed to participate in the study. We would like to thank Dr.Nilüfer Aylanç and Dr.Mehmet Aşık for their support.

Conflicts of interest: The authors have no conflicts of interest to disclose.

Funding: No financial support was received for this study.

\section{REFERENCES}

1. Mussa A, De Andrea M, Motta M, Mormile A, Palestini N, Corrias A. Predictors of Malignancy in Children with Thyroid Nodules. J Pediatr. 2015 Oct;167(4):886-892.

2. Niedziela M. Pathogenesis, diagnosis and management of thyroid nodules in children. Endocr Relat Cancer 2006;13:427-53.

3. Niedziela M. Thyroid nodules. Best Pract Res Clin Endocrinol Metab 2014;28:245-77.

4. Dean DS, Gharib H. Epidemiology of thyroid nodules. Best Pract Res Clin Endocrinol Metab 2008;22:901-11.

5. Cooper DS, Doherty GM, Haugen BR, Kloos RT, Lee SL, Mandel SJ, Mazzaferri EL, Mciver B, Pacini F, Schlumberger M, Sherman SI, Steward DL, Tuttle RM. Revised American Thyroid Association management guidelines for patients with thyroid nodules and differentiated thyroid cancer. American Thyroid Association (ATA) Guidelines Taskforce on Thyroid Nodules and Differentiated Thyroid Cancer. Thyroid. 2009;19:1167-1214.

6. Khurana KK, Labrador E, Izquierdo R, Mesonero CE, P1sharodı LR. The role of fine-needle aspiration biopsy in the management of thyroid nodules in children, adolescents, and young adults: a multi-institutional study. Thyroid. 1999;9: 383-386.

7. Gupta A, Ly S, Castroneves LA, Frates MC, Benson CB, Feldman HA, et al. A standardized assessment of thyroid nodules in children confirms higher cancer prevalence than in adults. J Clin Endocrinol Metab 2013;98:3238-45.

8. Corrıas A, Mussa A, Baronıo F, Arrıgo T, Salerno M, Segnı M, Vıgone MC, Gastaldı R, Zırıllı G, Tulı G, Beccarıa L, Iughettı L, Eınaudı S, Weber G, DE Luca F. Diagnostic features of thyroid nodules in pediatrics. Arch Pediatr Adolesc Med. 2010;164:714719.

9. Aghini-Lombardi F, Antonangelı L, Martıno E, Vıttı P, Maccherını D, Leolı F, Rago T, Grasso L, Valerıano R, Balestrıerı A, P1nchera A. The spectrum of thyroid disorders in an iodine-deficient community: the Pescopagano survey. J Clin Endocrinol Metab 1999;84: 561-566.

10. Hansen PS, Brıx TH, Bennedbaek FN, Bonnema SJ, Iachıne I, Kyvık KO, Hegedüs L. The relative importance of genetic and environmental factors in the etiology of thyroid nodularity: a study of healthy Danish twins. Clin Endocrinol (Oxf).2005; 62: 380386.

11. Taş F, Bulut S, Eğilmez H, Oztoprak I, Ergür AT, Candan F. Normal thyroid volume by ultrasonography in healthy children. Ann Trop Paediatr.2002;22: 375-379.

12. CASTRO, M.R., GHARİB, H. (2000). Thyroid nodules and cancer. Postgrad Med. 107: 113-124. 
13. Dittmar M, Libich C, Brenzel T, Kahaly GJ. Increased familial clustering of autoimmune thyroid diseases. Horm Metab Res. 2011;43: 200-204.

14. Sadowskı SM, He M, Gesuwan K, Gulatı N, Celi F, Merıno M, Nilubol N, Kebebew E. Prospective screening in familial nonmedullary thyroid cancer. Surgery. 2013;154:1194-1198.

15. Langer P, Tajtáková M, Bohov P, Klımes I. Possible role of genetic factors in thyroid growth rate and in the assessment of upper limit of normal thyroid volume in iodine-replete adolescents. Thyroid. 1999;9: 557-562.

16. Halac I, Zimmerman D. Thyroid nodules and cancers in children. Endocrinol Metab Clin North Am 2005;34: 725-774.

17. Baş VN, Aycan Z, Cetinkaya S, Uner C, Cavuşoğlu YH, Arda N. Thyroid nodules in children and adolescents: a single institution's experience. J Pediatr Endocrinol Metab. 2012;25: 633-638.

18. Arda IS, Yıldırım S, Demırhan B, Firat S. Fine needle aspiration biopsy of thyroid nodules. Arch Dis Child 2001;85: 313-317.

19. Erdoğan G, Erdoğan MF, Delange F, Sav H, Güllü S, Kamel N. Moderate to severe iodine deficiency in three endemic goitre areas from the Black Sea region and the capital of Turkey. Eur J Epidemiol 2000;16:1131-1134.

20. Erdoğan MF, Demır O, Emral R, Kamel AN, Erdoğan G. More than a decade of iodine prophylaxis is needed to eradicate goiter among school age children in a moderately iodine-deficient region. Thyroid. 2009;19: 265-268. 